\title{
Mannose-Binding Lectin Binds to Amyloid $\beta$ Protein and Modulates Inflammation
}

\author{
Mykol Larvie, ${ }^{1}$ Timothy Shoup, ${ }^{2}$ Wei-Chuan Chang, ${ }^{3}$ \\ Lorencia Chigweshe, ${ }^{3}$ Kevan Hartshorn, ${ }^{4}$ Mitchell R. White, ${ }^{4}$ Gregory L. Stahl, ${ }^{5}$ \\ David R. Elmaleh, ${ }^{2}$ and Kazue Takahashi ${ }^{3}$ \\ ${ }^{1}$ Divisions of Neuroradiology and Nuclear Medicine and Molecular Imaging, Department of Radiology, \\ Massachusetts General Hospital, Harvard Medical School, Boston, MA 02114, USA \\ ${ }^{2}$ Division of Nuclear Medicine and Molecular Imaging, Department of Radiology, Massachusetts General Hospital, \\ Harvard Medical School, Boston, MA 02114, USA \\ ${ }^{3}$ Department of Pediatrics, Massachusetts General Hospital, Harvard Medical School, Boston, MA 02114, USA \\ ${ }^{4}$ Department of Medicine, Boston University School of Medicine, Boston, MA 02118, USA \\ ${ }^{5}$ Department of Anesthesiology, Perioperative and Pain Medicine, Center for Experimental Therapeutics and Reperfusion Injury, \\ Harvard Institute of Medicine, Harvard Medical School, Boston, MA 02115, USA
}

Correspondence should be addressed to Kazue Takahashi, ktakahashi1@partners.org

Received 15 September 2011; Revised 26 November 2011; Accepted 4 December 2011

Academic Editor: Misao Matsushita

Copyright ( $\odot 2012$ Mykol Larvie et al. This is an open access article distributed under the Creative Commons Attribution License, which permits unrestricted use, distribution, and reproduction in any medium, provided the original work is properly cited.

\begin{abstract}
Mannose-binding lectin (MBL), a soluble factor of the innate immune system, is a pattern recognition molecule with a number of known ligands, including viruses, bacteria, and molecules from abnormal self tissues. In addition to its role in immunity, MBL also functions in the maintenance of tissue homeostasis. We present evidence here that MBL binds to amyloid $\beta$ peptides. MBL binding to other known carbohydrate ligands is calcium-dependent and has been attributed to the carbohydrate-recognition domain, a common feature of other C-type lectins. In contrast, we find that the features of MBL binding to $\mathrm{A} \beta$ are more similar to the reported binding characteristics of the cysteine-rich domain of the unrelated mannose receptor and therefore may involve the MBL cysteine-rich domain. Differences in MBL ligand binding may contribute to modulation of inflammatory response and may correlate with the function of MBL in processes such as coagulation and tissue homeostasis.
\end{abstract}

\section{Introduction}

The innate immune system provides the first line of host defense, and in healthy individuals this defense is constitutively present and active. Successful innate immune protection is achieved through two steps: first, identifying targets, such as pathogens and abnormal self-tissue and cells; second, orchestrating humoral and cellular effectors to eliminate the identified targets and induce appropriate host responses, including appropriate inflammation and resolution. Cellular elements of the innate immune system include phagocytes, macrophages, epithelial cells, and endothelial cells. Humoral components include pattern recognition molecules, complement proteins, coagulation proteins, and cytokines. Moreover, in addition to immune functions, the innate immune system includes coagulation and inflammation functions that are essential to the maintenance of tissue homeostasis $[1,2]$.

Activation of the innate immune system can be initiated by pattern recognition molecules, which are present on a variety of innate immune cells, bound within the extracellular matrix, and circulating as soluble molecules in blood. One such soluble pattern recognition molecule is mannose-binding lectin (MBL), which is primarily $(>95 \%)$ synthesized in the liver and secreted to circulate in the blood [3-6]. Although MBL protein has also been found in other organs, such as skin, brain, and lung, its mRNA has not been detected in those areas $[3,4,7-10]$, suggesting that MBL may be recruited to regions where its targets are located. MBL modulates inflammation in infection and tissue injury $[2,11,12]$, 
with extensive interactivity with inflammatory and other complement pathways $[13,14]$. Concerted action of these systems is required to maintain homeostasis, as dysfunction may result in impaired immunity, autoimmunity, or other disorder of homeostasis.

Genetic variation resulting in MBL deficiency is a common primary immunodeficiency [15-22]. There are three single-nucleotide polymorphisms (SNPs) in the MBL gene, located in the coding region of the collagen-like domain and in the promoter region. Heterozygosity in these SNP loci accounts for the majority of MBL deficiency, resulting in a wide range of MBL blood concentrations, from undetectable to as high as $10 \mu \mathrm{g} / \mathrm{mL}[19,20]$. Additionally, MBL blood levels vary with age and have been found to decrease significantly beyond the age of 40 [23]. MBL deficiency increases susceptibility to certain pathogens, as we have reviewed previously and as revealed in subsequent animal infection studies on pathogens, including influenza A virus (IAV) and Staphylococcus aureus (SA) [7, 11, 12, 24-30]. Animal studies have also provided in vivo evidence that $\mathrm{MBL}$ modulates inflammation $[2,7,11,12]$.

MBL functions as an opsonin and activates the lectin complement pathway through association with MBL-associated serine proteases (MASPs) $[1,3,7,31,32]$. In humans, there are three proteolytically active MASPs: MASP-1, MASP-2, and MASP-3. MASPs form complexes with MBL $[33,34]$, and MBL binding to specific ligands is thought to induce conformational changes that enhance the proteolytic activity of the associated MASP. Recent results, including our own, provide evidence that MBL and MASP 1-3 complexes also mediate coagulation [1, 31, 35-37] pathways.

Structurally, MBL comprises a cysteine-rich domain at the N-terminus followed by a collagen-like domain, a neck region and a carbohydrate recognition domain (CRD) at the C-terminus [24]. Three single-MBL peptides of $35 \mathrm{kD}$ associate to form a functional trimeric subunit that further multimerizes to form higher-order oligomers, as large as hexamers of trimers [24]. MBL recognizes many pathogens, including bacteria and viruses, as well as abnormal self tissues that contain endogenous neoepitopes that are exposed on apoptotic cells, cell debris, and injured and damaged tissues [3, 24, 38, 39]. These MBL targets contain chemical patterns, including D-mannose, L-fucose, and $N$-acetyl-D-glucosamine $[3,24,38-42]$. To date, investigation of MBL ligand binding has been focused on various carbohydrates and has been principally attributed to the CRD. As the MBL CRD requires calcium to bind many ligands, it is regarded as a member of the C-type lectin family.

Another C-type lectin, mannose receptor (MR), is a membrane receptor that yields a soluble form of its extracellular domain as a cleavage product [43]. MR has 8 CRDs at its C-terminus, preceded by a type II fibronectin-like domain and a cysteine-rich domain (CysD) at its N-terminus [44]. CysD has been found to bind to sulfated carbohydrate residues of luteinizing hormone and blood type-determining Lewis saccharides [45]. Such CysD-mediated MR target binding is calcium independent $[46,47]$, in contrast to calcium requirement for ligand binding within the CRD. There are three cysteine residues in an 18 amino acid stretch within the CysD of MBL, and 5 cysteines within an 84 amino acid stretch within the CysD of MR $[47,48]$. Although there is otherwise little amino acid homology within the CysDs of $\mathrm{MBL}$ and MR, it is possible that these CysDs share similar physiochemical properties that enable binding to sulfated carbohydrates.

Sulfated polysaccharides are abundant throughout the body. Extracellular tissue matrices throughout the body are rich in glycosaminoglycans, which are sulfated polysaccharides [49] and sulfated proteoglycans.

We have previously identified important roles for MBL and innate immunity in maintenance of tissue homeostasis $[1,2]$. We have considered whether these homeostatic mechanisms may relate to the brain, and specifically we have tested the interaction of MBL with amyloid $\beta(\mathrm{A} \beta)$. $\mathrm{A} \beta$ has been associated with Alzheimer's disease (AD) $[50,51]$, and it has been observed that abnormal accumulation in $\mathrm{AD}$ is principally related to decreased clearance [52]. Consequently, we have developed the hypothesis that MBL plays a role in brain homeostasis that may include $\mathrm{A} \beta$ clearance.

We present data demonstrating that MBL, a pattern recognition of the innate immune system, recognizes specific chemical epitopes of bacterial and viral pathogens, represented here by Staphylococcus aureus and influenza A virus, as well as an endogenous epitope, represented by the amyloid $\beta$ molecule. This versatility demonstrates the central role of the innate immune system in providing immune protection from pathogens as well as maintaining homeostasis of selftissues. We also present investigations of the inflammatory responses related to these molecules in an in vitro system and discuss the potential implications of our findings.

\section{Materials and Methods}

2.1. Reagents. L-Fucose, sodium fucoidan (from Fucus vesiculosus, MW $170 \mathrm{kD}$ ), and sodium heparin (porcine, unfractionated) were purchased from Sigma-Aldrich. L-Fucose sulfate was synthesized according to the methods described by Forrester [53], yielding a mixture of monosubstituted Lfucose sulfates at different carbon centers. Figure 1 shows chemical structures of these sugars as well as mannan, the best characterized MBL ligand. Amyloid $\beta(\mathrm{A} \beta)$ peptides, both $\mathrm{A} \beta 40$ and $\mathrm{A} \beta 42$, were purchased from rPeptide and resuspended at $1 \mathrm{mg} / \mathrm{mL}$ according to the manufacturer's instruction. Aliquots were stored at $-80^{\circ} \mathrm{C}$ and sonicated (Branson, duty cycle 60 and output setting 6 , resulting in $30 \%$ output) prior to use.

Influenza A virus (IAV); strain A, Puerto Rico, 34 (referred to as PR8) was prepared as previously described [54]. Briefly, IAV was grown in the chorioallantoic fluid of chicken eggs and purified on a discontinuous sucrose gradient (Sigma-Aldrich). Virus stocks were dialyzed against PBS (SigmaAldrich), and aliquots were stored in a $-150^{\circ} \mathrm{C}$ freezer. Virus was sonicated prior to use, as for $\mathrm{A} \beta$. Hemagglutinin (HA) titers were determined by titration with human blood type $\mathrm{O}, \mathrm{Rh}^{-}$red blood cells (RBCs) in PBS. 

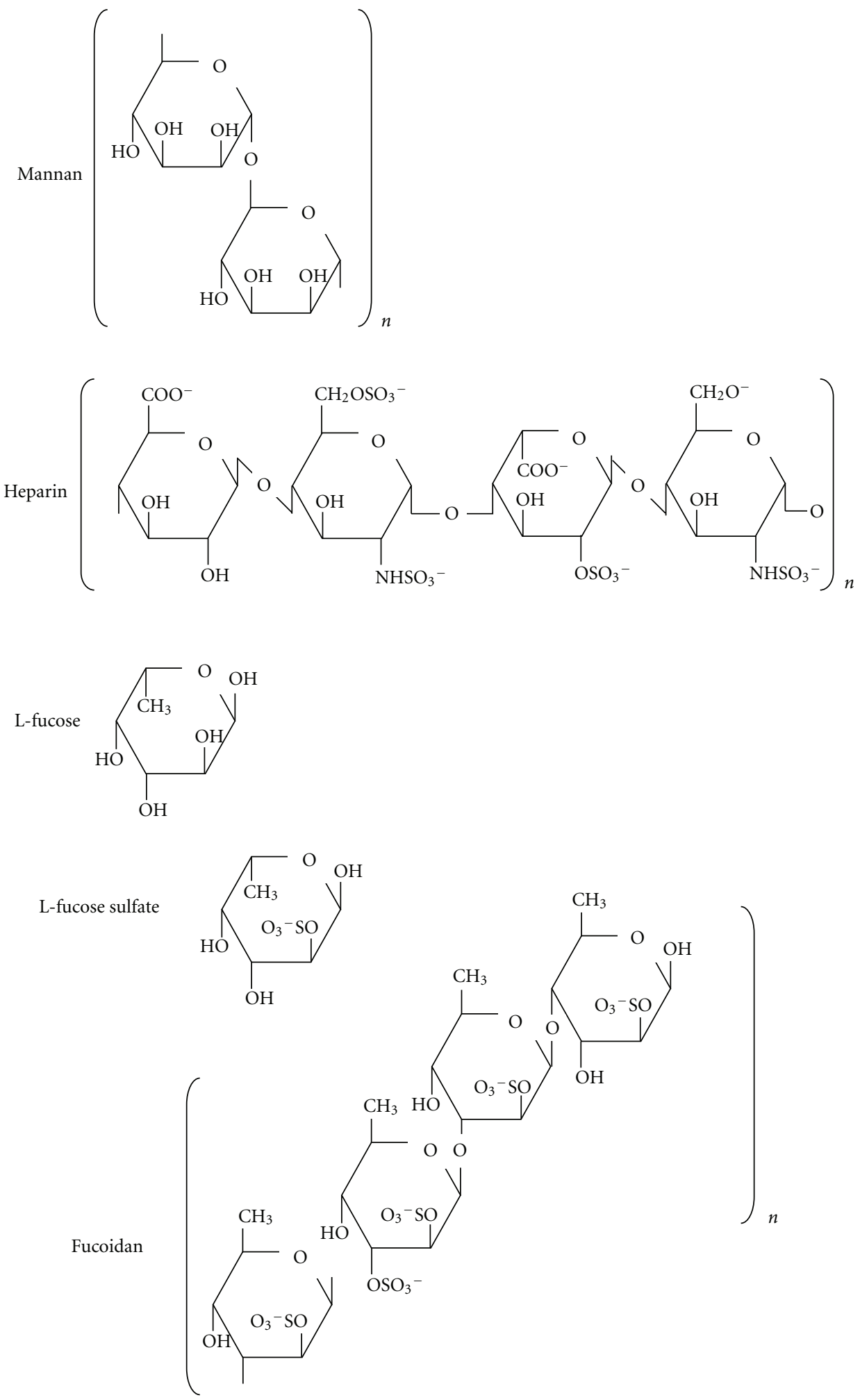

FIGURE 1: Chemical structures of polysaccharides used in this study, with the mannan structure for comparison. Representative repeating units are shown for mannan, heparin, and fucoidan. The average molecular weight of the fucoidan preparation used for this work is approximately $170 \mathrm{kD}$. The porcine heparin used in these experiments is unfractionated, with a range of different molecular weight species. L-fucose-2-sulfate is depicted here. 
S. aureus (SA) was grown in Columbia broth with $2 \%$ $\mathrm{NaCl}$ to a mid-log phase and washed with saline. Aliquots $\left(5 \times 10^{8}\right.$ colony forming units $\left.(\mathrm{cfu}) / \mathrm{mL}\right)$ were stored at $-20^{\circ} \mathrm{C}$.

Recombinant human MBL (MBL) was a gift from Enzon Pharmaceuticals Inc.

2.2. MBL Binding Assay. These assays were performed as previously described, with minor modifications [11]. Initially, $\mathrm{A} \beta$ peptides were tested using concentrations of $0.05,5,500$, and $50,000 \mathrm{ng} / \mathrm{mL}$ to measure the dose response of MBL binding. Subsequently, A $\beta$ peptides were used at 50,000 ng/ $\mathrm{mL}$ for all other studies. Assays were carried out in 384 well polystyrene plates with $20 \mu \mathrm{L}$ total volume per well. Wells were coated with $A \beta 40, A \beta 42$, IAV (strain PR8, $1000^{-1}$ hemagglutinin titer $/ \mathrm{mL}$ ), or $S$. aureus (Reynolds, $5 \times 10^{5} \mathrm{cfu}$ ) in $20 \mu \mathrm{L}$ of $0.2 \mathrm{M}$ carbonate buffer, $\mathrm{pH} 9.5$, and incubated $12 \mathrm{~h}$ at $4^{\circ} \mathrm{C}$. After rinsing with $10 \mathrm{mM}$ Tris, $\mathrm{pH} 7.4,120 \mathrm{mM}$ $\mathrm{NaCl}$ (TBS) with $10 \mathrm{mM} \mathrm{CaCl}_{2}$ and $0.5 \%$ Tween 20 (washing buffer), plates were blocked with $0.1 \%$ BSA in TBS-Ca buffer for $1 \mathrm{hr}$ at room temperature with gentle agitation. Test samples were diluted in TBS-Ca buffer to $2 \mu \mathrm{g} / \mathrm{mL}$ of MBL. Excess liquid was shaken off and test samples $(20 \mu \mathrm{L} /$ well $)$ were added and incubated as above. Where indicated, carbohydrate inhibitors were added. After rinsing, bound MBL was detected by incubating with anti-MBL antibody (2A9) [55], followed by alkaline phosphatase-conjugated goat antimouse IgG (1:7500, Promega) and pNPP substrate solution (Sigma-Aldrich). Reactions were read at OD $415 \mathrm{~nm}$ using a Spectramax plate reader (Molecular Devices). Results are expressed as OD $415 \mathrm{~nm}$ reading as well as \% of MBL alone.

For carbohydrate inhibition studies, carbohydrate compounds were used at $5 \mathrm{mg} / \mathrm{mL}$, which is within the usual range used for MBL binding inhibition. For the monosaccharides, L-Fucose and L-fucose sulfate, this represents $27 \mathrm{mM}$ and $13 \mathrm{mM}$, respectively, which is in the range of the reported $50 \%$ inhibitory concentrations of L-fucose for MBL [56]. In tests of calcium dependency, 20 mM EDTA was used.

2.3. Mice and Mice Sera. MBL null mice were previously generated and fully backcrossed onto C57Black/6J $[2,11]$. Sera were collected by cardiac puncture of euthanized mice and sera from at least 5 mice were pooled and aliquots were stored at $-80^{\circ} \mathrm{C}$. All animal experiments were performed under a protocol approved by the Subcommittee on Research Animal Care at Massachusetts General Hospital, Boston, MA, USA.

2.4. Cytokine Assay. Peritoneal macrophages (MФ) of wild type C57Black/6J (Jackson Laboratories) were prepared by peritoneal lavage performed 4-5 days after intraperitoneal injection of $2 \mathrm{~mL}$ of $3 \%$ thioglycolate (DIFCO). Assays were performed using 96 well plates. МФs were plated at $1 \times$ $10^{5}$ per well in $50 \mu \mathrm{L}$ RPMI culture medium containing $10 \%$ serum of wild type or MBL null mice and cultured at least $1 \mathrm{hr}$ in a $5 \% \mathrm{CO}_{2}$ incubator at $37^{\circ} \mathrm{C}$ to allow MФs adhere to the plate. A $\beta 40(1 \mu \mathrm{g}), \mathrm{A} \beta 42(1 \mu \mathrm{g})$, IAV (strain PR8, 1000-1 hemagglutinin titer), or $S$. aureus (Reynolds, $1 \times 10^{6} \mathrm{cfu}$ ) was prepared in $10 \%$ serum of wild type or MLB null mice. To test the inhibitory effects of a sulfated polysaccharide, heparin was added to a final concentration of $0,0.1,1$, or $10 \mu \mathrm{g} / \mathrm{mL}$ in a total volume of $100 \mu \mathrm{L}$ per well. Plates were cultured for $2 \mathrm{hrs}$ at $37^{\circ} \mathrm{C}$ in a $5 \% \mathrm{CO}_{2}$ incubator. $70 \mu \mathrm{L}$ of culture supernatant was collected into $\mathrm{U}$ bottom plates and stored at $-80^{\circ} \mathrm{C}$ for subsequent measurement of cytokines. Assays were performed in duplicate.

IL- 6 and TNF- $\alpha$ were assayed using ELISA kits (DuoSet, R\&D systems) according to the manufacturer's instruction. Supernatant was diluted to $1: 10$ and $1: 1$ for the IL- 6 and TNF- $\alpha$ assays, respectively. Results are expressed as $\mathrm{pg} / \mathrm{mL}$ of IL- 6 and TNF- $\alpha$.

2.5. Statistical Analysis. All data was analyzed by Student's $t$-test using JMP software (SAS Institute Inc.). $P$ values less than 0.05 are considered to be significant.

\section{Results}

3.1. MBL Binds to A $\beta$ Peptides. There is dose-dependent binding of MBL to $A \beta$ peptides, within increased binding of MBL in the presence of increased amounts of $A \beta$ (Figure 2). Under the reaction conditions tested here, there was similar binding of MBL to $A \beta 40$ (Figure 2(a)) and $A \beta 42$ (Figure $2(\mathrm{~b})$ ), and similar dose dependence. We next evaluated the specificity of the MBL binding to $\mathrm{A} \beta$ using multiple inhibitors.

3.2. MBL Ligand Binding Is Inhibited by Polysaccharides, and More Strongly Inhibited by Sulfated Polysaccharides. Based upon the observation that sulfated polysaccharides are recognized by the CysD of MR [46], we investigated MBL ligand binding in the presence of different nonsulfated and sulfated carbohydrates. MBL binding to A $\beta$ peptides was compared with MBL binding to IAV and SA. L-Fucose, a well-known inhibitor of MBL binding, did not significantly inhibit MBL binding to $A \beta$, although it did significantly inhibit MBL binding to IAV and SA, as expected (Figure 3 ). In contrast, sulfated carbohydrates such as L-fucose sulfate, fucoidan, and heparin showed significant inhibition of MBL binding to all targets. The inhibition caused by sulfated carbohydrates was significantly greater with MBL binding to $\mathrm{A} \beta$ compared with MBL binding to virus and bacteria and was most pronounced with heparin. These results demonstrate that there is specificity of MBL binding to the tested ligands, as this binding is inhibited by specific carbohydrates. However, there is a difference between MBL binding to $A \beta$, which is not significantly inhibited by L-fucose (a known competitive inhibitor of binding to the MBL CRD) and MBL binding to IAV and SA. Additionally, whereas sulfated carbohydrates (Lfucose sulfate, fucoidan, and heparin) strongly inhibit MBL binding to $A \beta$, they are relatively weak inhibitors of MBL binding to IAV and SA.

3.3. Calcium Dependency of MBL Ligand Binding. We tested the calcium dependence of the most effective inhibitors identified in the previous experiment, fucoidan and heparin, 


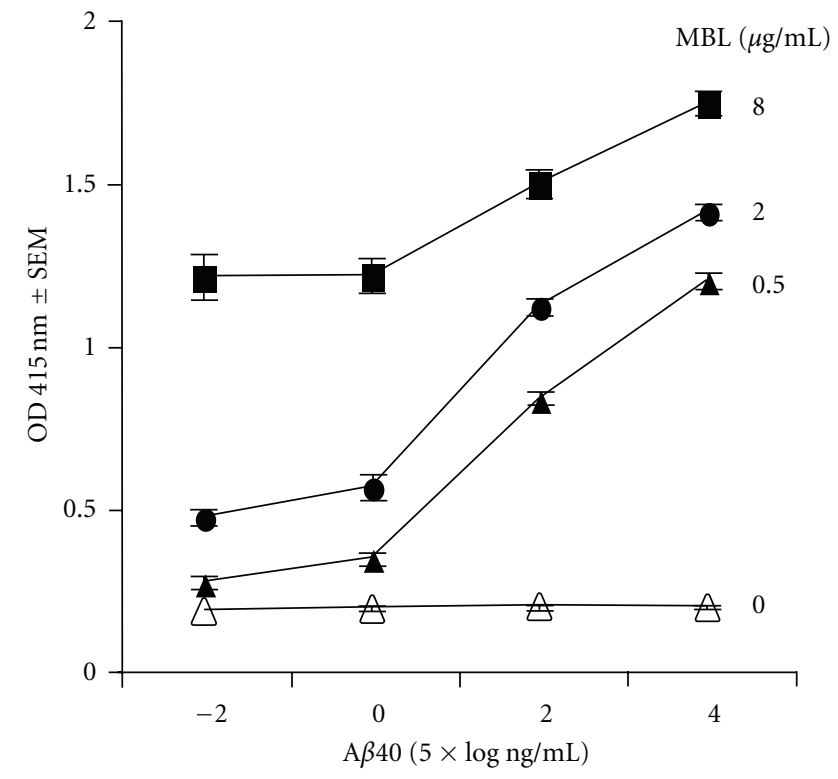

(a)

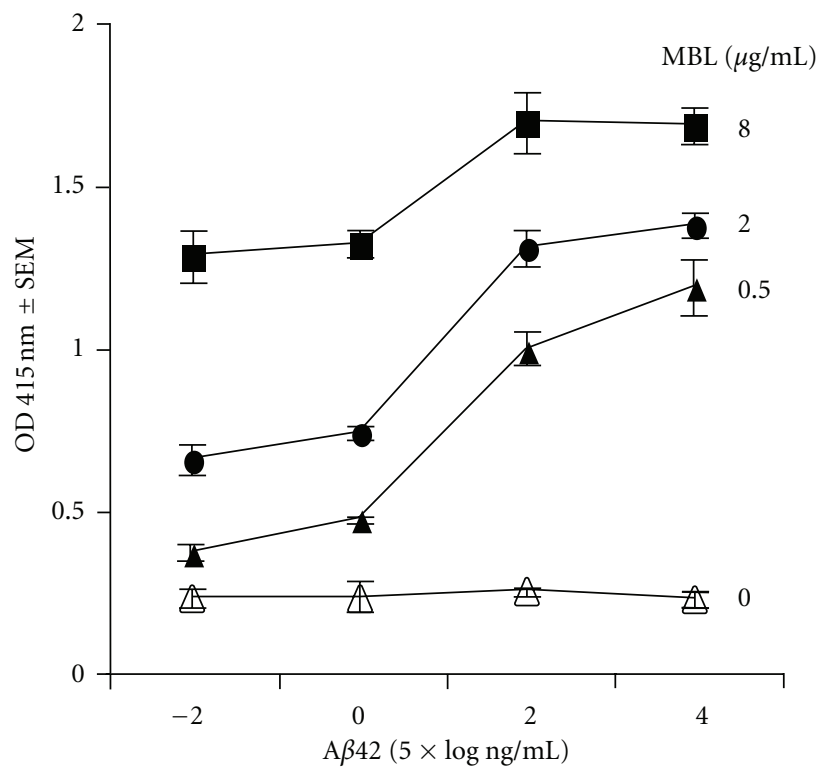

(b)

Figure 2: Dose response of MBL binding to A $\beta 40$ (a) and A $\beta 42$ (b) peptides. MBL binding to A $\beta$ was measured with $A \beta$ peptide concentrations of $0.05,5,500$, and 50,000 $\mathrm{ng} / \mathrm{mL}$ (Figure 2). Assays were performed in triplicate, as described in Section 2. Data are expressed as mean \pm SEM.

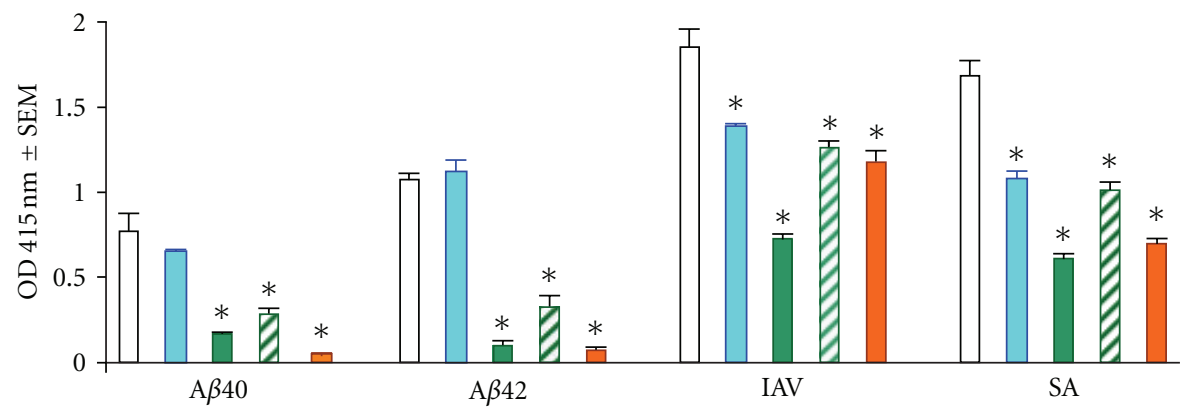

(a)

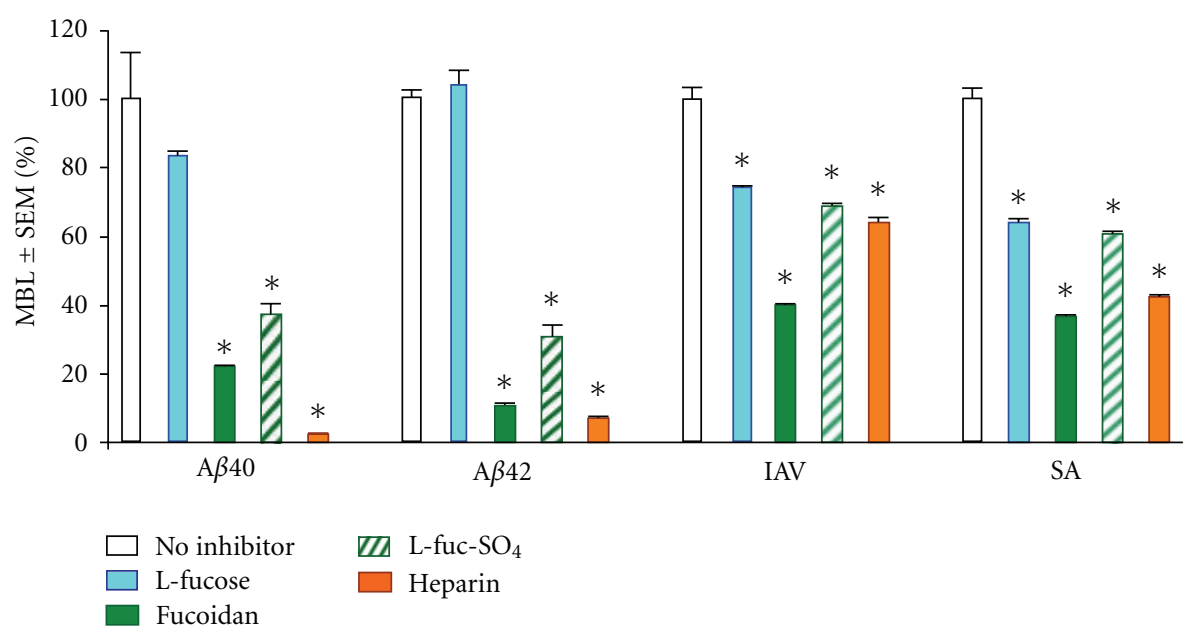

(b)

FIgure 3: Carbohydrate inhibition of MBL binding to A $\beta 40, \mathrm{~A} \beta 42, \mathrm{IAV}$, and SA. MBL binding is expressed as OD $415 \mathrm{~nm}$ (a) and \% of MBL alone (b). Assays were performed in triplicate, as described in Section $2 .{ }^{*} P<0.0001$ compared to MBL with no inhibitor. 


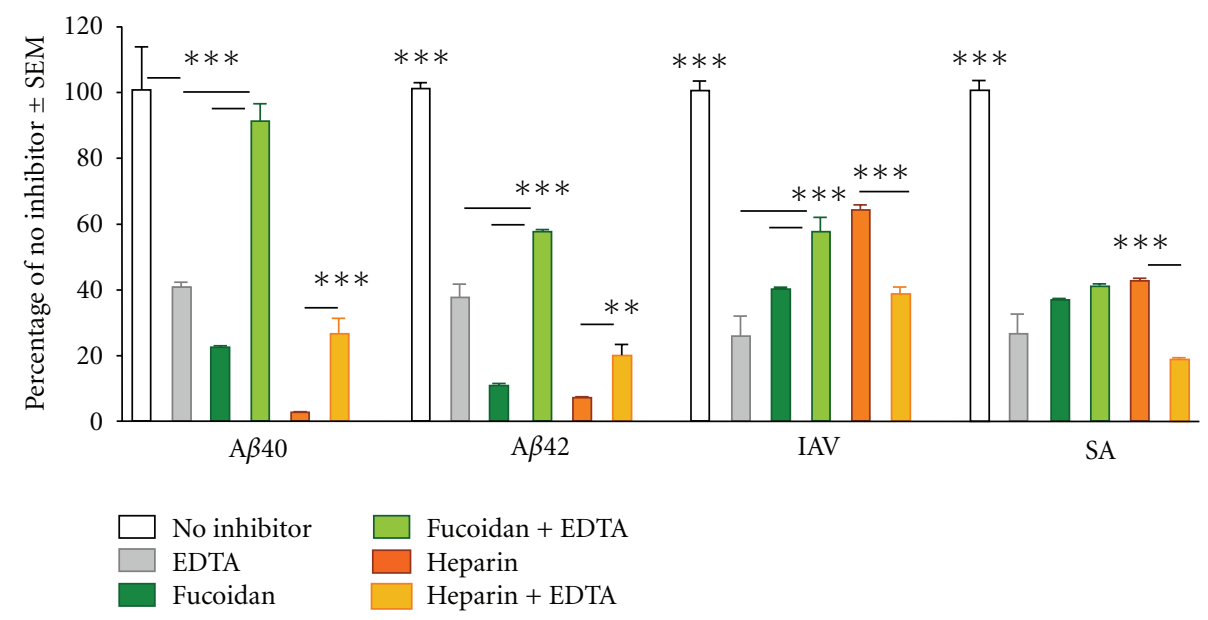

FIgURE 4: Effect of calcium depletion on carbohydrate inhibition of MBL binding to A $\beta 40, A \beta 42, I A V$, and SA. MBL binding is expressed as $\%$ of MBL binding with no inhibitor. Assays were performed in triplicate, as described in Section 2. Statistical significance compared to EDTA effect: ${ }^{*} P<0.01 ; * * P<0.005$; and ${ }^{* * *} P<0.0001$.

both of which are sulfated polysaccharides. CRD-mediated ligand binding is calcium dependent, whereas CysD-mediated ligand binding is not. EDTA inhibits MBL-binding to all tested ligands (Figure 4), which is consistent with the hypothesis that the MBL CRD is involved with binding to each them. Similarly, the sulfated carbohydrates fucoidan and heparin both inhibit MBL binding to all tested ligands. Surprisingly, however, EDTA together with sulfated carbohydrate showed decreased inhibition of MBL binding to $A \beta$. This contrasts with the increased inhibition of MBL binding to both IAV and SA with the combination of heparin and EDTA. The apparent relief of inhibition of MBL binding to $\mathrm{A} \beta$ caused by EDTA suggests that impairing binding through the $\mathrm{CRD}$, by removing $\mathrm{Ca}^{2+}$, potentiates MBL binding to $\mathrm{A} \beta$, perhaps through a domain other than the MBL CRD.

3.4. MBL Modulates Inflammatory Responses of Macrophages. Production of IL- 6 and TNF- $\alpha$ from WT macrophages in response to $A \beta$ peptides, IAV or SA was examined with serum from wild type or MBL null mice. IL-6 production was significantly higher in MBL null serum compared to WT serum (Figure 5(a)). Moreover, IL-6 production was significantly higher in the presence of SA compared to all other ligands (Figure 5(a)).

In contrast, TNF- $\alpha$ production was slightly higher in WT serum, although this was not statistically significant (Figure 5(b)). In both MBL null and WT sera, SA, and A $\beta 42$ peptide provoked significantly higher TNF- $\alpha$ production compared with medium alone (Figure 5(b)). In contrast, $A \beta 40$ peptide had no significant effect on TNF- $\alpha$ production. IAV provoked trace TNF- $\alpha$ production in MBL null serum, and showed no significant difference compared with media alone in WT serum.

3.5. TNF- $\alpha$ and IL-6 Production Is Modulated by Heparin. We next examined the effect of heparin, an endogenous sulfated polysaccharide, on inflammatory responses of peritoneal macrophages. IL-6 production in both MBL null and WT sera was significantly inhibited by $10 \mu \mathrm{g} / \mathrm{mL}$ of heparin with all ligands: SA, IAV, and $A \beta$ peptides (Figures $6(\mathrm{a})-6(\mathrm{~d})$ ). Heparin's inhibitory effect was also observed at $1 \mu \mathrm{g} / \mathrm{mL}$ for IAV and $A \beta 40$ peptide (Figures 6(b) and 6(c)).

TNF- $\alpha$ production in WT serum was significantly inhibited by $10 \mu \mathrm{g} / \mathrm{mL}$ of heparin with all ligands: $\mathrm{SA}, \mathrm{IAV}$, and $\mathrm{A} \beta$ peptides (Figures $6(\mathrm{e})-6(\mathrm{~h})$ ). For both $\mathrm{A} \beta 40$ and $A \beta 42$, inhibition was also observed in MBL null serum (Figures 6(g) and $6(\mathrm{~h})$ ). In contrast, heparin significantly increased TNF- $\alpha$ production in MBL null serum with SA, while there was no TNF-a production in MBL null serum with IAV, as before (Figures 6(e) and 6(f)).

\section{Discussion}

Our data demonstrate that MBL binds to IAV, SA, and $\mathrm{A} \beta$ peptides. We have previously reported MBL binding to IAV and $S A$; however, binding to $A \beta$ peptide is reported here for the first time. MBL recognition of $A \beta$ is demonstrated to be specific, as it is disrupted by specific inhibitors. Carbohydrates, and especially sulfated polysaccharides, inhibit MBL binding to $\mathrm{A} \beta$ as well as to SA and IAV ligands. The effects of EDTA, which removes $\mathrm{Ca}^{2+}$ required by the MBL CRD for ligand binding, vary depending on the ligand. Based on this data, we put forward the hypothesis that in addition to ligand recognition through its $\mathrm{CRD}$, MBL may bind certain ligands through another moiety, and we suggest that the CysD is a likely candidate for an alternative binding site.

Interestingly, MBL binding to $A \beta$ peptides, unlike virus and bacteria, was not inhibited by L-fucose, which is known to bind in a calcium-dependent manner to the MBL CRD. This finding is consistent with MBL binding to $A \beta$ outside the CRD. However, EDTA, which chelates and removes $\mathrm{Ca}^{2+}$ from the MBL CRD, does inhibit MBL-A $\beta$ interaction, suggesting that the carbohydrate recognition mechanisms of the MBL CRD may be more complex. Mannan and GlcNAc, which are widely used as specific inhibitors of MBL ligand 


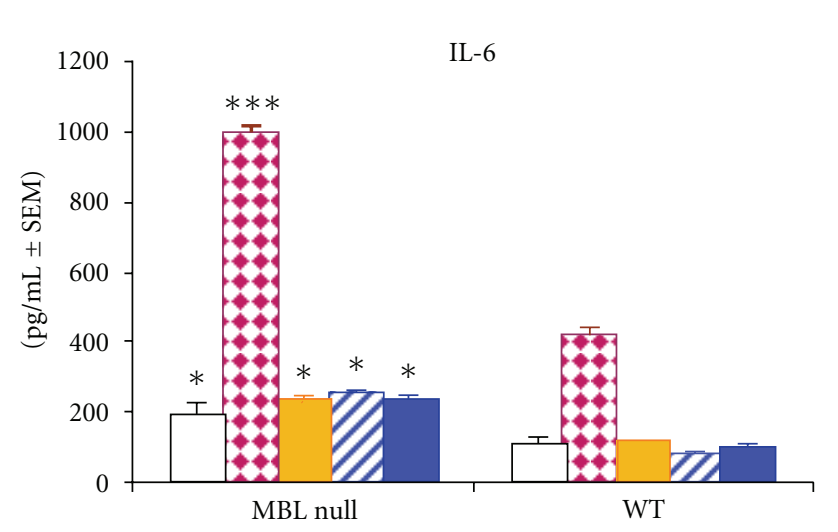

$\begin{array}{ll}\square \text { Medium } & \square \mathrm{A} \beta 40 \\ \text { SA } & \square \mathrm{A} \beta 42 \\ \square \text { IAV } & \end{array}$

(a)
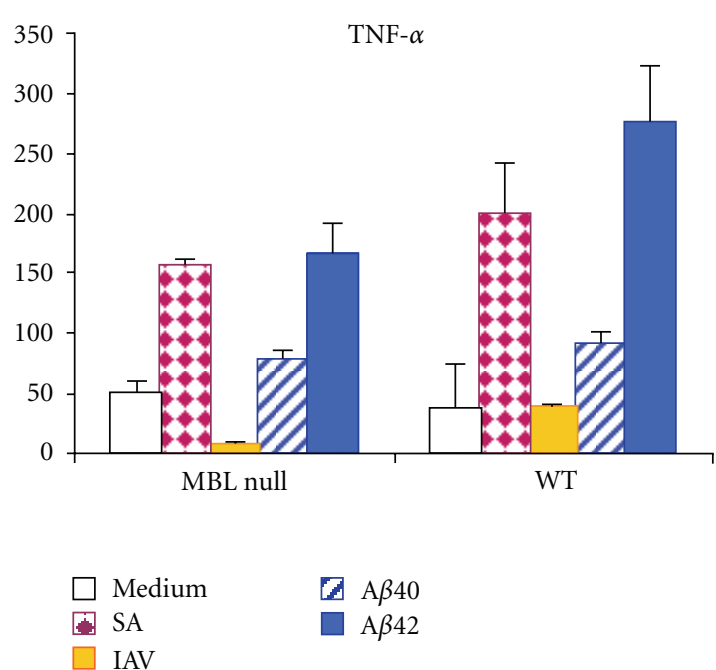

(b)

FIgURE 5: Cytokine release from macrophages in response to A $\beta 40, \mathrm{~A} \beta 42$, IAV, or SA. Sera from wild type (WT, MBL sufficient) or MBL null (MBL deficient) mice were incubated with peritoneal macrophages in the presence of the ligand indicated by the bar graph legend, as described in section 2. Assays were performed in duplicate. IL- 6 and TNF- $\alpha$ in the culture supernatant are expressed as pg/mL \pm SEM. Comparing MBL null versus WT responses: ${ }^{*} P<0.05$ and ${ }^{* * *} P<0.0001$.

binding, do not inhibit MBL binding to $\mathrm{A} \beta$ interaction (data not shown). Furthermore, EDTA diminishes the inhibitory effects of heparin and fucoidan on MBL binding to $\mathrm{A} \beta$ peptides, and particularly $\mathrm{A} \beta 40$. Taken together, these results suggest that the MBL CRD with a ligand other than $\mathrm{Ca}^{2+}$ bound may impair the ligand binding ability of the MBL CysD.

Our results also show interaction of $\mathrm{MBL}$ and heparin, which inhibits binding of MBL to $\mathrm{A} \beta$, IAV, and SA. This appears to be a new finding, although our experiments are not definitive. In our work demonstrating abnormality in bleeding time in MBL null mice, we related this phenomenon to MBL activation of a thrombin-like activity that contributes to coagulation, and which when deficient resulted in decreased coagulation [1]. The findings presented here suggest that these systems may be more complex, with MBL binding to endogenous anticoagulant glycosaminoglycans (such as heparins) possibly contributing to thrombosis, and further investigation is needed to understand the mechanisms and significance of this phenomenon.

Although we have not performed rigorous experiments to determine the affinity of MBL binding to the ligands tested here, there was significantly greater MBL binding to IAV and SA compared with $\mathrm{A} \beta$ peptides. It is difficult to compare these different types of ligands, as the $\mathrm{A} \beta$ peptides are in an undefined state of aggregation, and the IAV and SA both present a complex and heterogeneous surface. For example, SA expresses lipoteichoic acid, wall teichoic acid, and capsular polysaccharides, while IAV expresses hemagglutinin that is heterogeneously glycosylated. It is also possible that these pathogens may have multiple ligands that can be recognized by the MBL CRD and CysD independently, resulting in increased $\mathrm{MBL}$ binding. We are currently undertaking derivative studies to better characterize $\mathrm{MBL}$ binding to different ligands, including different forms of $\mathrm{A} \beta$.
We have previously reported that MBL is a proinflammatory molecule. For instance, production of inflammatory cytokines, including IL-6 and TNF- $\alpha$, was significantly lower in MBL null mice sera at an early time point ( 2 hours) following SA blood infection in vivo [11]. Other subsequent in vitro studies provided concordant data that MBL facilitates induction of TNF- $\alpha$ and IL- 6 from macrophages [57]. Baseline TNF- $\alpha$ levels are similar in MBL null and WT sera, and overall TNF- $\alpha$ production in response to SA and $\mathrm{A} \beta$ peptide is slightly higher (not statistically significant) in WT serum than MBL null serum. Although the effects of TNF- $\alpha$ have been considered in the brain, it is not clear that its effects are harmful or beneficial [58]. Although TNF- $\alpha$ production by macrophages in response to $\mathrm{A} \beta 42$ peptide has been reported, the role of MBL in this process has not been investigated [59].

Interestingly, TNF- $\alpha$ production by peritoneal macrophages was undetectable in response to IAV in MBL null serum, but not in WT serum. MBL has been shown to bind to and even neutralize IAV $[7,60]$. Therefore, it is possible that in our experimental system MBL played a role in making IAV available to the macrophages, and these results support our previous observations that MBL promotes TNF- $\alpha$ production in response to stimuli. Similarly, $\mathrm{A} \beta$ peptides, in particular $\mathrm{A} \beta 42$, appear to stimulate $\mathrm{TNF}-\alpha$ production from macrophages, and this process is enhanced in MBL sufficient WT serum compared to MBL null serum.

In contrast, IL-6 production is significantly higher in MBL null serum compared to WT serum in response to all stimuli: IAV, SA, and A $\beta$ peptides. These results contrast with our previous paper, which also studied murine macrophages but with $1 \%$ fetal bovine serum [61], and it is possible that cytokine responses may differ depending on the serum used (unpublished observations). Although production of both TNF- $\alpha$ and IL- 6 is stimulated by NF $\kappa$ B pathways, our results support the concept that there are additional factors related to cytokine production $[62,63]$. 
IL-6 $(\mathrm{pg} / \mathrm{mL} \pm \mathrm{SEM})$

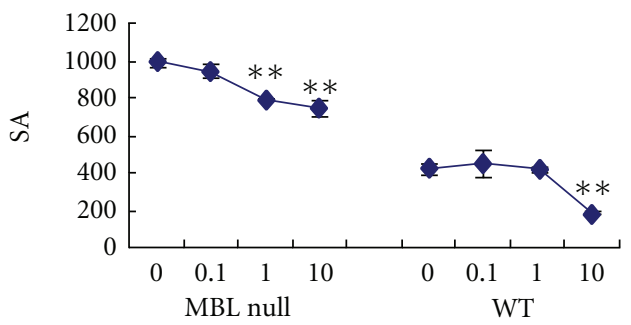

(a)

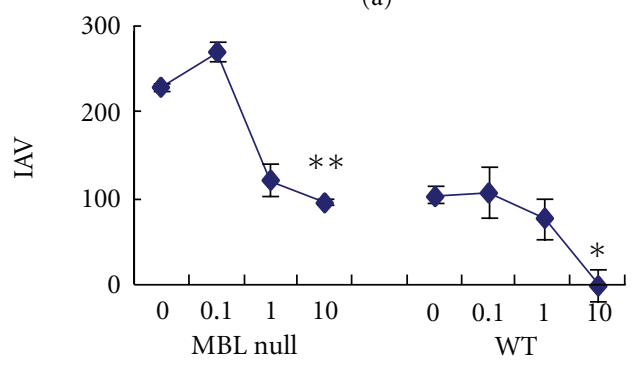

(b)

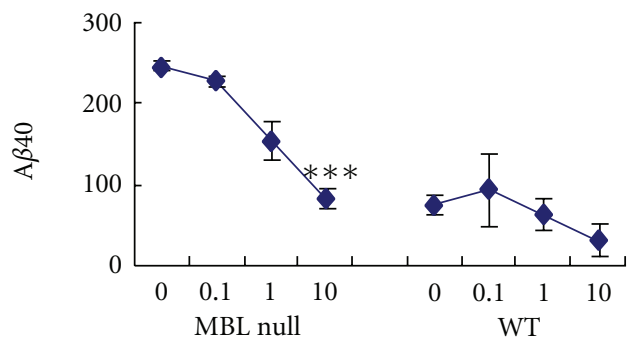

(c)

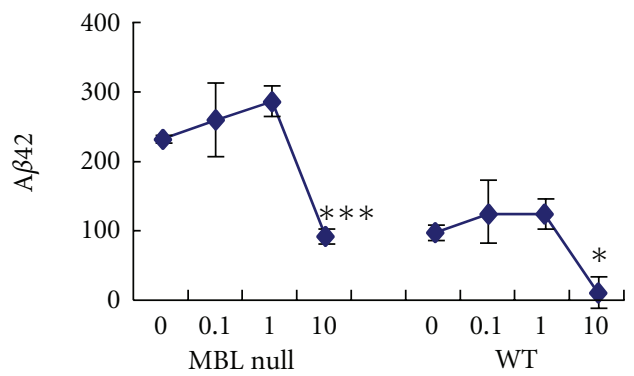

(d)

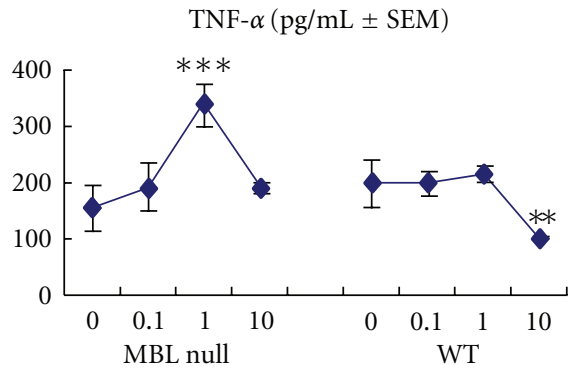

(e)

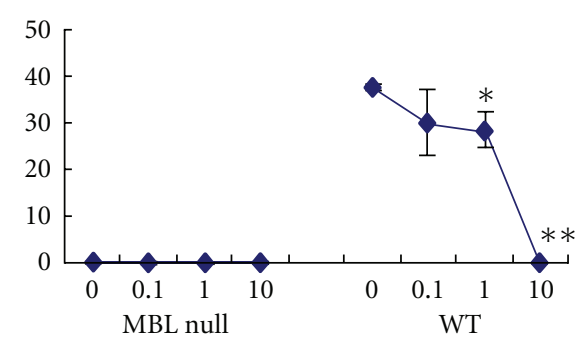

(f)

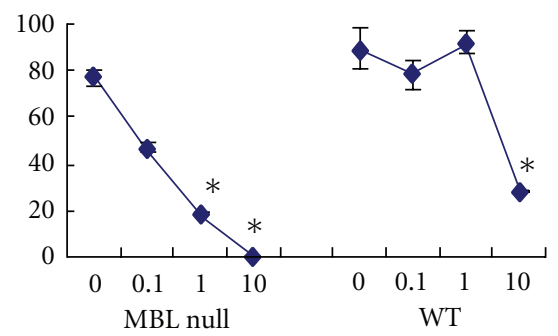

(g)

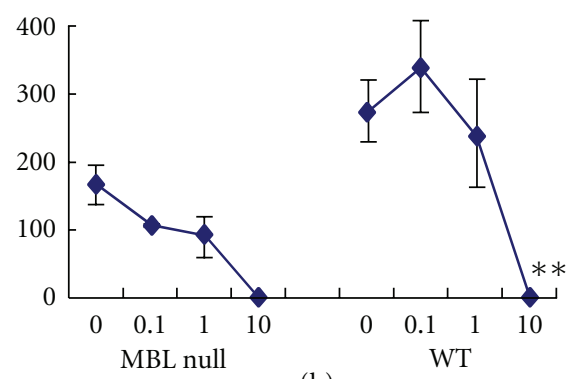

(h)

Figure 6: Effects of heparin on cytokine responses to A $\beta 40, \mathrm{~A} \beta 42, \mathrm{IAV}$, or SA. The assays were performed as in Figure 5 . Heparin was used at $0,0.1,1$, and $10 \mu \mathrm{g} / \mathrm{mL}$ mixed with $\mathrm{A} \beta 40, \mathrm{~A} \beta 42$, IAV, or SA. IL- 6 and TNF- $\alpha$ in the culture supernatant were determined and are expressed as $\mathrm{pg} / \mathrm{mL} \pm \mathrm{SEM}$. Compared to WT serum, ${ }^{*} P<0.05 ;{ }^{* *} P<0.005 ;{ }^{* * *} P<0.0001$ against all others.

The inflammatory responses of peritoneal macrophages in our system were significantly inhibited by heparin, and particularly IL-6 production in MBL null serum. A similar inhibitory effect was also observed for TNF- $\alpha$, with the exception of response to IAV and SA in the absence of MBL. MBL null mice are susceptible to these pathogens, as we previously reported, and deranged inflammatory modulation related to heparin in the absence of MBL may also contribute to susceptibility to infection $[7,11]$. We note that the greatest inhibitory effects in our system were observed at heparin levels of $10 \mu \mathrm{g} / \mathrm{mL}$, corresponding to 1.76 units $/ \mathrm{mL}$. As tissue heparin is reportedly on the order of 1-45 units/g, the levels used here can be achieved locally in tissues [64].
The inhibitory effects of heparin on inflammation reported here support previous speculation that heparin may reduce $\mathrm{A} \beta$-mediated inflammation [65]. Likewise, this antiinflammatory activity may be related to the beneficial effects of exogenous low-molecular-weight heparin in a mouse model of amyloidopathy [66]. Heparin has also been shown to modify amyloid precursor protein processing and $\mathrm{A} \beta$ aggregation [67-69].

In conclusion, our investigations demonstrate that $\mathrm{MBL}$ binds to a variety of ligands, including $\mathrm{A} \beta$ peptides, possibly through both the CRD and CysD regions. Further, it is possible that some ligands, such as $\mathrm{A} \beta$, may preferentially bind to the CysD, as depicted in Figure 7. We have found that MBL 
Proposed modes of target recognition by MBL
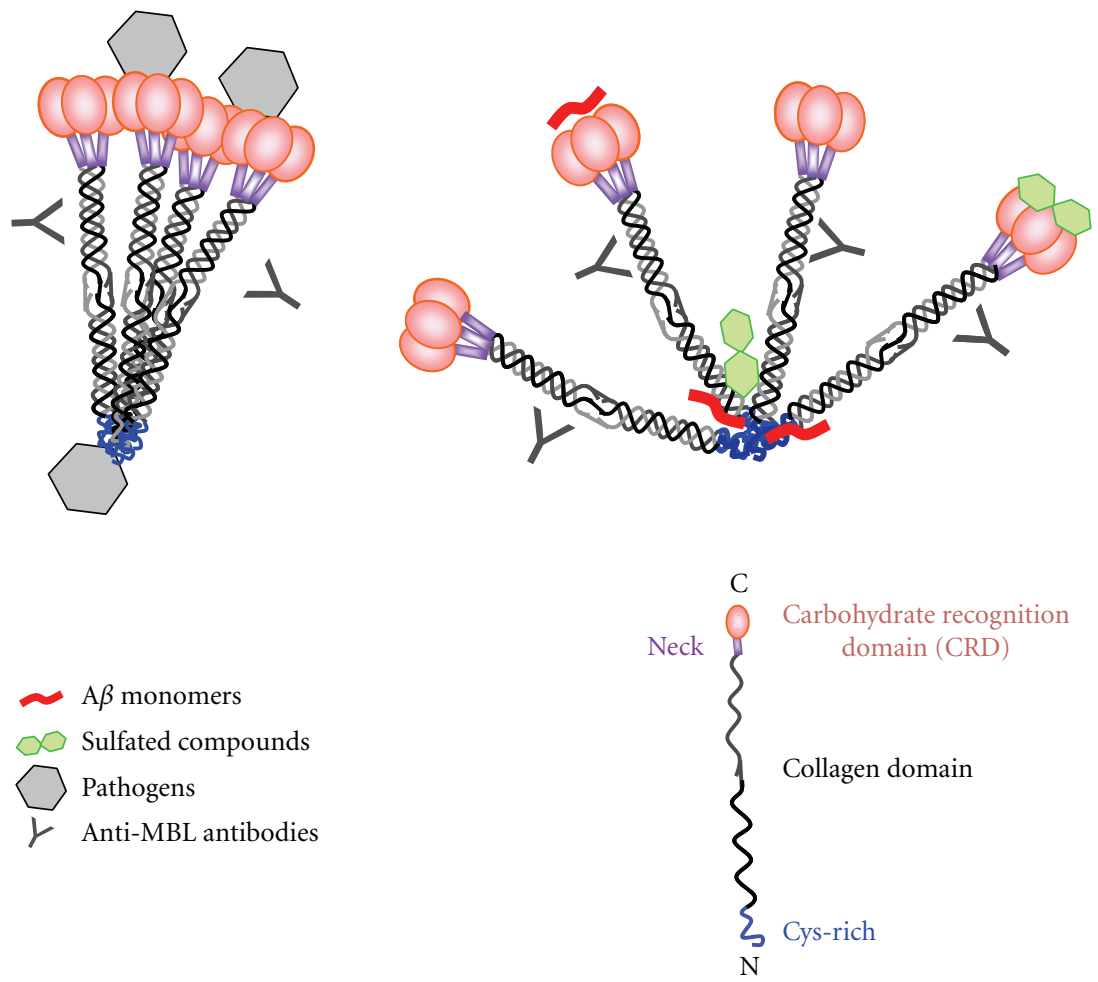

$35 \mathrm{kD}$ monomer

Figure 7: A proposed model of MBL-ligand-binding modes. Figures on the right and left both represent tetramers of MBL trimers. On the left, the MBL molecule is shown binding to pathogens by both the CRD and CysD regions. On the right, sulfated carbohydrates are depicted binding to both the CRD and CysD regions, which may inhibit binding of ligands, including A $\beta$, to the CysD. Additionally, the CRDs may have alternative bindings modes, which allow recognition of carbohydrate and noncarbohydrates, possibly including A $\beta$. Antibodies are shown binding to the collagen domain of MBL, corresponding to the anti-MBL antibodies used in the ELISA experiments reported here.

binding to different ligands results in modulation of the inflammatory response with peritoneal macrophages. Additionally, MBL binding to pathogens may have different effects depending upon the ligand composition of the pathogen surface $[61,70]$.

The possibility of different ligand-binding modes for MBL leads to the hypothesis that MBL plays different roles in different host systems, such as immunity, coagulation, and homeostasis. With respect to the latter, our finding that $\mathrm{MBL}$ recognizes $A \beta$ leads to consideration of the role of these different systems in the maintenance of brain homeostasis. Specifically, in recognition that $\mathrm{A} \beta$ clearance is insufficient in Alzheimer's disease patients $[52,71]$, we propose that $\mathrm{MBL}$ may play a role in $\mathrm{A} \beta$ clearance, which may be a normal element of brain homeostasis.

\section{Abbreviations}

A $\beta: \quad$ Amyloid $\beta$

BSA: $\quad$ Bovine serum albumin

CysD: Cysteine-rich domain

CRD: Carbohydrate recognition domain

GlcNAc: N-acetyl-D-glucosamine
MBL: Mannose-binding lectin

MASP: MBL-associated serine protease

SNPs: Single-nuclear polymorphisms

TNF- $\alpha$ : Tumor necrosis factor- $\alpha$

IL-6: Interleukin-6.

\section{Acknowledgments}

This paper was supported in part by grants from NIH U01 AI074503. The authors thank Enzon Pharmaceutical Inc. for recombinant human MBL.

\section{References}

[1] K. Takahashi, W. C. Chang, M. Takahashi et al., "Mannosebinding lectin and its associated proteases (MASPs) mediate coagulation and its deficiency is a risk factor in developing complications from infection, including disseminated intravascular coagulation," Immunobiology, vol. 216, no. 1-2, pp. 96-102, 2011.

[2] M. Moller-Kristensen, M. R. Hamblin, S. Thiel, J. C. Jensenius, and K. Takahashi, "Burn injury reveals altered phenotype in mannan-binding lectin-deficient mice," Journal of Investigative Dermatology, vol. 127, no. 6, pp. 1524-1531, 2007. 
[3] K. Takahashi, W. E. Ip, I. C. Michelow, and R. A. Ezekowitz, "The mannose-binding lectin: a prototypic pattern recognition molecule," Current Opinion in Immunology, vol. 18, no. 1, pp. 16-23, 2006.

[4] K. Uemura, M. Saka, T. Nakagawa et al., "L-MBP is expressed in epithelial cells of mouse small intestine," Journal of Immunology, vol. 169, no. 12, pp. 6945-6950, 2002.

[5] D. L. Grasso, L. Segat, E. Zocconi, O. Radillo, C. Trevisiol, and S. Crovella, "MBL expression in patients with recurrent tonsillitis," International Journal of Pediatric Otorhinolaryngology, vol. 73, no. 11, pp. 1550-1553, 2009.

[6] R. Bulla, F. de Seta, O. Radillo et al., "Mannose-binding lectin is produced by vaginal epithelial cells and its level in the vaginal fluid is influenced by progesterone," Molecular Immunology, vol. 48, no. 1-3, pp. 281-286, 2010.

[7] W. C. Chang, M. R. White, P. Moyo et al., "Lack of the pattern recognition molecule mannose-binding lectin increases susceptibility to influenza A virus infection," BMC Immunology, vol. 11, no. 1, p. 64, 2010.

[8] M. L. Lokitz, W. Zhang, M. Bashir et al., "Ultraviolet-B recruits mannose-binding lectin into skin from non-cutaneous sources," Journal of Investigative Dermatology, vol. 125, no. 1, pp. 166-173, 2005.

[9] K. J. Fidler, T. N. Hilliard, A. Bush et al., "Mannose-binding lectin is present in the infected airway: a possible pulmonary defence mechanism," Thorax, vol. 64, no. 2, pp. 150-155, 2009.

[10] P. H. Yager, Z. You, T. Qin et al., "Mannose binding lectin gene deficiency increases susceptibility to traumatic brain injury in mice," Journal of Cerebral Blood Flow and Metabolism, vol. 28, no. 5, pp. 1030-1039, 2008.

[11] L. Shi, K. Takahashi, J. Dundee et al., "Mannose-binding lectin-deficient mice are susceptible to infection with Staphylococcus aureus," Journal of Experimental Medicine, vol. 199, no. 10, pp. 1379-1390, 2004.

[12] M. Møller-Kristensen, W. K. Ip, L. Shi et al., "Deficiency of mannose-binding lectin greatly increases susceptibility to postburn infection with Pseudomonas aeruginosa," Journal of Immunology, vol. 176, no. 3, pp. 1769-1775, 2006.

[13] C. T. Esmon, "Crosstalk between inflammation and thrombosis," Maturitas, vol. 47, no. 4, pp. 305-314, 2004.

[14] R. Bobowiec, J. Wessely-Szponder, and P. Hola, "Crosstalk between coagulation and inflammation in mastitis and metritis in dairy cows," Acta Veterinaria Hungarica, vol. 57, no. 2, pp. 283-293, 2009.

[15] M. Super, S. D. Gillies, S. Foley et al., "Distinct and overlapping functions of allelic forms of human mannose binding protein," Nature Genetics, vol. 2, no. 1, pp. 50-55, 1992.

[16] H. O. Madsen, P. Garred, S. Thiel et al., "Interplay between promoter and structural gene variants control basal serum level of mannan-binding protein," Journal of Immunology, vol. 155, no. 6, pp. 3013-3020, 1995.

[17] H. O. Madsen, P. Garred, J. A. Kurtzhals et al., "A new frequent allele is the missing link in the structural polymorphism of the human mannan-binding protein," Immunogenetics, vol. 40, no. 1, pp. 37-44, 1994.

[18] P. Garred, F. Larsen, H. O. Madsen, and C. Koch, "Mannosebinding lectin deficiency-revisited," Molecular Immunology, vol. 40, no. 2-4, pp. 73-84, 2003.

[19] R. Steffensen, S. Thiel, K. Varming, C. Jersild, and J. C. Jensenius, "Detection of structural gene mutations and promoter polymorphisms in the mannan-binding lectin (MBL) gene by polymerase chain reaction with sequence-specific primers," Journal of Immunological Methods, vol. 241, no. 1-2, pp. 33 42, 2000.
[20] H. O. Madsen, M. L. Satz, B. Hogh, A. Svejgaard, and P. Garred, "Different molecular events result in low protein levels of mannan- binding lectin in populations from Southeast Africa and South America," Journal of Immunology, vol. 161, no. 6, pp. 3169-3175, 1998.

[21] P. Garred, F. Larsen, J. Seyfarth, R. Fujita, and H. O. Madsen, "Mannose-binding lectin and its genetic variants," Genes and Immunity, vol. 7, no. 2, pp. 85-94, 2006.

[22] C. D. Collard, S. K. Shernan, A. A. Fox et al., "The MBL2 "LYQA secretor" haplotype is an independent predictor of postoperative myocardial infarction in whites undergoing coronary artery bypass graft surgery," Circulation, vol. 116, 11, pp. I106-I112, 2007.

[23] W. K. Ip, Y. F. To, S. K. Cheng, and Y. L. Lau, "Serum mannose-binding lectin levels and mbl2 gene polymorphisms in different age and gender groups of southern Chinese adults," Scandinavian Journal of Immunology, vol. 59, no. 3, pp. 310314, 2004.

[24] K. Takahashi and R. A. Ezekowitz, "The role of the mannosebinding lectin in innate immunity," Clinical Infectious Diseases, vol. 41, supplement 7, pp. S440-S444, 2005.

[25] K. K. Singh, A. Lieser, P. K. Ruan, T. Fenton, and S. A. Spector, "An age-dependent association of mannose-binding lectin-2 genetic variants on HIV-1-related disease in children," Journal of Allergy and Clinical Immunology, vol. 122, no. 1, pp. 173$180,2008$.

[26] W. C. van der Zwet, A. Catsburg, R. M. van Elburg, P. H. Savelkoul, and C. M. Vandenbroucke-Grauls, "Mannosebinding lectin (MBL) genotype in relation to risk of nosocomial infection in pre-term neonates in the neonatal intensive care unit," Clinical Microbiology and Infection, vol. 14, no. 2, pp. 130-135, 2008.

[27] C. G. Mullighan, S. L. Heatley, S. Danner et al., "Mannosebinding lectin status is associated with risk of major infection following myeloablative sibling allogeneic hematopoietic stem cell transplantation," Blood, vol. 112, no. 5, pp. 2120-2128, 2008.

[28] C. T. Tran, K. Kjeldsen, S. Haunso, N. Høiby, H. K. Johansen, and M. Christiansen, "Mannan-binding lectin is a determinant of survival in infective endocarditis," Clinical and Experimental Immunology, vol. 148, no. 1, pp. 101-105, 2007.

[29] J. Faber, T. Schuessler, A. Finn et al., "Age-dependent association of human mannose-binding lectin mutations with susceptibility to invasive meningococcal disease in childhood," Pediatric Infectious Disease Journal, vol. 26, no. 3, pp. 243-246, 2007.

[30] M. Gadjeva, S. R. Paludan, S. Thiel et al., "Mannan-binding lectin modulates the response to HSV-2 infection," Clinical and Experimental Immunology, vol. 138, no. 2, pp. 304-311, 2004.

[31] A. Krarup, R. Wallis, J. S. Presanis, P. Gál, and R. B. Sim, “Simultaneous activation of complement and coagulation by MBLassociated serine protease 2," PLoS ONE, vol. 2, no. 7, article e623, 2007.

[32] W. C. Chang, K. L. Hartshorn, M. R. White et al., "Recombinant chimeric lectins consisting of mannose-binding lectin and L-ficolin are potent inhibitors of influenza A virus compared with mannose-binding lectin," Biochemical Pharmacology, vol. 81, no. 3, pp. 388-395, 2011.

[33] M. R. Dahl, S. Thiel, M. Matsushita et al., "MASP-3 and its association with distinct complexes of the mannan-binding lectin complement activation pathway," Immunity, vol. 15, no. 1, pp. 127-135, 2001. 
[34] K. Tateishi, T. Kanemoto, T. Fujita, and M. Matsushita, "Characterization of the complex between mannose-binding lectin trimer and mannose-binding lectin-associated serine proteases," Microbiology and Immunology, vol. 55, no. 6, pp. 427433, 2011.

[35] J. S. Presanis, K. Hajela, G. Ambrus, P. Gál, and R. B. Sim, "Differential substrate and inhibitor profiles for human MASP-1 and MASP-2," Molecular Immunology, vol. 40, no. 13, pp. 921929, 2004.

[36] K. C. Gulla, K. Gupta, A. Krarup et al., "Activation of mannanbinding lectin-associated serine proteases leads to generation of a fibrin clot," Immunology, vol. 129, no. 4, pp. 482-495, 2010.

[37] Y. Endo, N. Nakazawa, D. Iwaki, M. Takahashi, M. Matsushita, and T. Fujita, "Interactions of ficolin and mannose-binding lectin with fibrinogen/fibrin augment the lectin complement pathway," Journal of Innate Immunity, vol. 2, no. 1, pp. 33-42, 2010.

[38] J. A. Hoffmann, F. C. Kafatos, C. A. Janeway, and R. A. Ezekowitz, "Phylogenetic perspectives in innate immunity," Science, vol. 284, no. 5418, pp. 1313-1318, 1999.

[39] D. A. Fraser and A. J. Tenner, "Directing an appropriate immune response: the role of defense collagens and other soluble pattern recognition molecules," Current Drug Targets, vol. 9, no. 2, pp. 113-122, 2008.

[40] J. S. Haurum, S. Thiel, H. P. Haagsman, S. B. Laursen, B. Larsen, and J. C. Jensenius, "Studies on the carbohydratebinding characteristics of human pulmonary surfactant-associated protein A and comparison with two other collectins: mannan-binding protein and conglutinin," Biochemical Journal, vol. 293, no. 3, pp. 873-878, 1993.

[41] T. Kawasaki, R. Etoh, and I. Yamashina, "Isolation and characterization of a mannan-binding protein from rabbit liver," Biochemical and Biophysical Research Communications, vol. 81, no. 3, pp. 1018-1024, 1978.

[42] M. M. Estabrook, D. L. Jack, N. J. Klein, and G. A. Jarvis, "Mannose-Binding Lectin Binds to Two Major Outer Membrane Proteins, Opacity Protein and Porin, of Neisseria meningitidis," Journal of Immunology, vol. 172, no. 6, pp. 37843792, 2004

[43] S. A. Linehan, L. Martínez-Pomares, and S. Gordon, "Macrophage lectins in host defence," Microbes and Infection, vol. 2, no. 3, pp. 279-288, 2000.

[44] N. Harris, M. Super, M. Rits, G. Chang, and R. A. B. Ezekowitz, "Characterization of the murine macrophage mannose receptor: demonstration that the downregulation of receptor expression mediated by interferon- $\gamma$ occurs at the level of transcription," Blood, vol. 80, no. 9, pp. 2363-2373, 1992.

[45] C. Leteux, W. Chai, R. W. Loveless et al., "The cysteine-rich domain of the macrophage mannose receptor is a multispecific lectin that recognizes chondroitin sulfates A and B and sulfated oligosaccharides of blood group Lewisa and Lewis(x) types in addition to the sulfated N-glycans of lutropin," Journal of Experimental Medicine, vol. 191, no. 7, pp. 11171126, 2000.

[46] D. Fiete, M. C. Beranek, and J. U. Baenziger, "The macrophage/endothelial cell mannose receptor cDNA encodes a protein that binds oligosaccharides terminating with SO4-4GalNAc $\beta 1,4$ GIcNAca $\beta$ or Man at independent sites," Proceedings of the National Academy of Sciences of the United States of America, vol. 94, no. 21, pp. 11256-11261, 1997.

[47] Y. Liu, A. J. Chirino, Z. Misulovin et al., "Crystal structure of the cysteine-rich domain of mannose receptor complexed with a sulfated carbohydrate ligand," Journal of Experimental Medicine, vol. 191, no. 7, pp. 1105-1116, 2000.

[48] R. A. Ezekowitz, L. E. Day, and G. A. Herman, "A human mannose-binding protein is an acute-phase reactant that shares sequence homology with other vertebrate lectins," Journal of Experimental Medicine, vol. 167, no. 3, pp. 1034-1046, 1988.

[49] H. E. Murrey and L. C. Hsieh-Wilson, "The chemical neurobiology of carbohydrates," Chemical Reviews, vol. 108, no. 5, pp. 1708-1731, 2008.

[50] D. J. Selkoe, "The molecular pathology of Alzheimer's disease," Neuron, vol. 6, no. 4, pp. 487-498, 1991.

[51] J. A. Hardy and G. A. Higgins, "Alzheimer's disease: the amyloid cascade hypothesis," Science, vol. 256, no. 5054, pp. 184$185,1992$.

[52] K. G. Mawuenyega, W. Sigurdson, V. Ovod et al., "Decreased clearance of CNS $\beta$-amyloid in Alzheimer's disease," Science, vol. 330, no. 6012, p. 1774, 2010.

[53] P. F. Forrester, P. F. Lloyd, and C. H. Stuart, "Synthesis of Lfucose 2-, 3-, and 4-sulphates," Carbohydrate Research, vol. 49, pp. 175-184, 1976.

[54] K. L. Hartshorn, M. Collamer, M. Auerbach, J. B. Myers, N. Pavlotsky, and A. I. Tauber, "Effects of influenza A virus on human neutrophil calcium metabolism," Journal of Immunology, vol. 141, no. 4, pp. 1295-1301, 1988.

[55] C. D. Collard, M. C. Montalto, W. R. Reenstra, J. A. Buras, and G. L. Stahl, "Endothelial oxidative stress activates the lectin complement pathway: role of cytokeratin 1," American Journal of Pathology, vol. 159, no. 3, pp. 1045-1054, 2001.

[56] S. Hansen, S. Thiel, A. Willis, U. Holmskov, and J. C. Jensenius, "Purification and characterization of two mannan-binding lectins from mouse serum," Journal of Immunology, vol. 164, no. 5, pp. 2610-2618, 2000.

[57] W. K. Eddie Ip, K. Takahashi, K. J. Moore, L. M. Stuart, and R. A. Ezekowitz, "Mannose-binding lectin enhances Toll-like receptors 2 and 6 signaling from the phagosome," Journal of Experimental Medicine, vol. 205, no. 1, pp. 169-181, 2008.

[58] E. Tobinick, "Tumour necrosis factor modulation for treatment of Alzheimer's disease: rationale and current evidence," CNS Drugs, vol. 23, no. 9, pp. 713-725, 2009.

[59] H. A. Smits, N. M. de Vos, J. W. Wat, T. van der Bruggen, J. Verhoef, and H. S. Nottet, "Intracellular pathways involved in TNF- $\alpha$ and superoxide anion release by A $\beta(1-42)$-stimulated primary human macrophages," Journal of Neuroimmunology, vol. 115, no. 1-2, pp. 144-151, 2001.

[60] T. Kase, Y. Suzuki, T. Kawai et al., "Human mannan-binding lectin inhibits the infection of influenza a virus without complement," Immunology, vol. 97, no. 3, pp. 385-392, 1999.

[61] W. K. Eddie Ip, K. Takahashi, K. J. Moore, L. M. Stuart, and R. A. Ezekowitz, "Mannose-binding lectin enhances Toll-like receptors 2 and 6 signaling from the phagosome," Journal of Experimental Medicine, vol. 205, no. 1, pp. 169-181, 2008.

[62] Y. Ben-Neriah and M. Karin, "Inflammation meets cancer, with NF- $\kappa \mathrm{B}$ as the matchmaker," Nature Immunology, vol. 12, no. 8, pp. 715-723, 2011

[63] W. K. Ip, K. Takahashi, R. A. Ezekowitz, and L. M. Stuart, "Mannose-binding lectin and innate immunity," Immunological Reviews, vol. 230, no. 1, pp. 9-21, 2009.

[64] L. Freeman, R. Posthuma, L. Gordon, and W. Marx, "Determination of tissue heparin," Archives of Biochemistry and Biophysics, vol. 70, no. 1, pp. 169-177, 1957.

[65] L. Bergamaschini, C. Donarini, E. Rossi, A. de Luigi, C. Vergani, and M. G. de Simoni, "Heparin attenuates cytotoxic and inflammatory activity of Alzheimer amyloid- $\beta$ in vitro," Neurobiology of Aging, vol. 23, no. 4, pp. 531-536, 2002. 
[66] N. M. Timmer, L. van Dijk, C. E. der Zee, A. Kiliaan, R. M. van de Waal, and M. M. Verbeek, "Enoxaparin treatment administered at both early and late stages of amyloid $\beta$ deposition improves cognition of APPswe/PS1dE9 mice with differential effects on brain A $\beta$ levels," Neurobiology of Disease, vol. 40, no. 1, pp. 340-347, 2010.

[67] H. Cui, A. C. Hung, D. W. Klaver et al., "Effects of heparin and enoxaparin on APP processing and $\mathrm{a} \beta$ production in primary cortical neurons from Tg2576 mice," PLoS ONE, vol. 6, no. 7, article e23007, 2011.

[68] E. Sandwall, P. O’Callaghan, X. Zhang, U. Lindahl, L. Lannfelt, and J. P. Li, "Heparan sulfate mediates amyloid-beta internalization and cytotoxicity," Glycobiology, vol. 20, no. 5, pp. 533$541,2010$.

[69] D. Klaver, A. C. Hung, R. Gasperini, L. Foa, M. I. Aguilar, and D. H. Small, "Effect of heparin on APP metabolism and A $\beta$ production in cortical neurons," Neurodegenerative Diseases, vol. 7, no. 1-3, pp. 187-189, 2010.

[70] X. Ji, G. G. Olinger, S. Aris, Y. Chen, H. Gewurz, and G. T. Spear, "Mannose-binding lectin binds to Ebola and Marburg envelope glycoproteins, resulting in blocking of virus interaction with DC-SIGN and complement-mediated virus neutralization," Journal of General Virology, vol. 86, no. 9, pp. 2535-2542, 2005.

[71] A. Kurz and R. Perneczky, "Amyloid clearance as a treatment target against Alzheimer's disease," Journal of Alzheimer's Disease, vol. 24, supplement 2, pp. 61-73, 2011. 

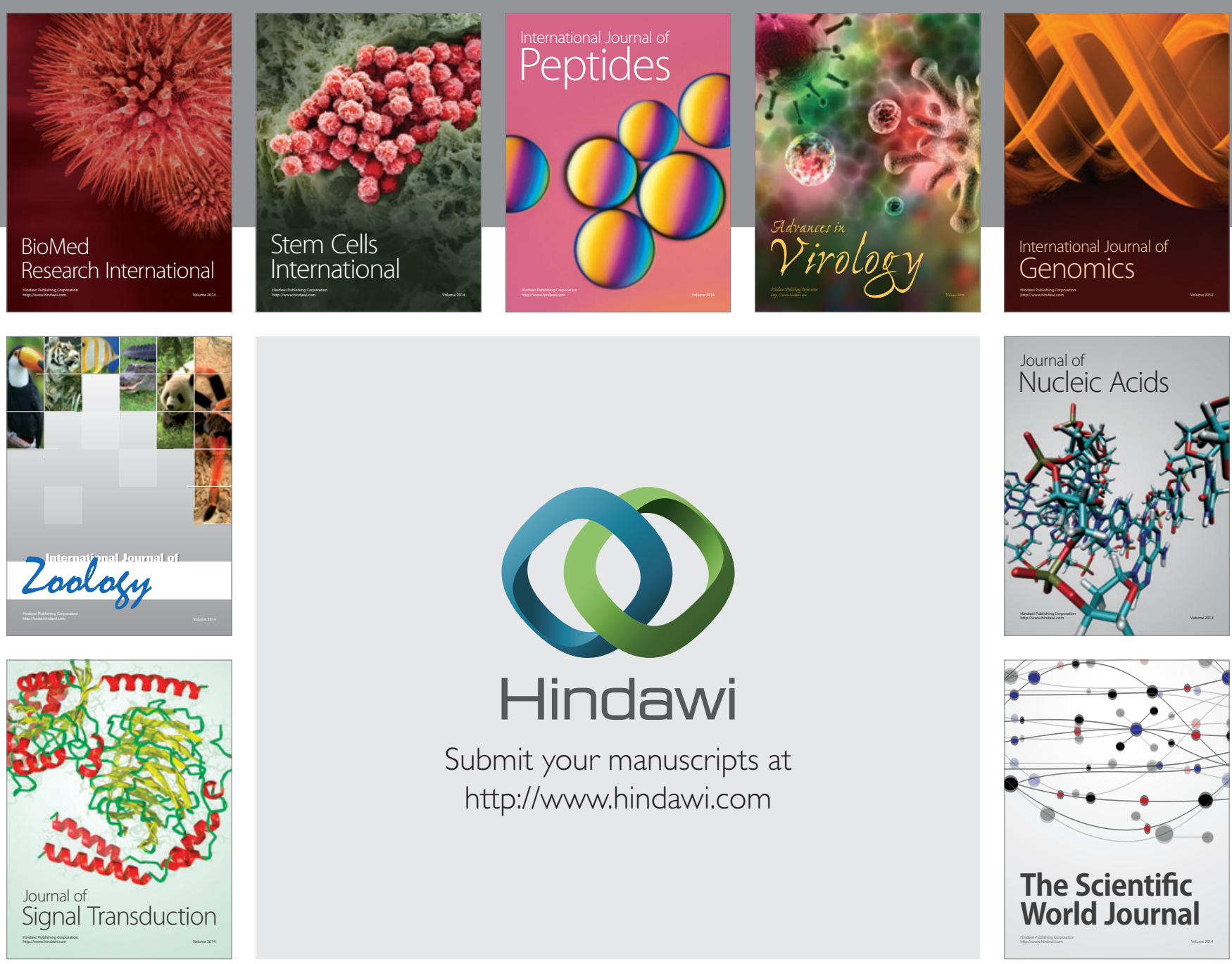

Submit your manuscripts at

http://www.hindawi.com
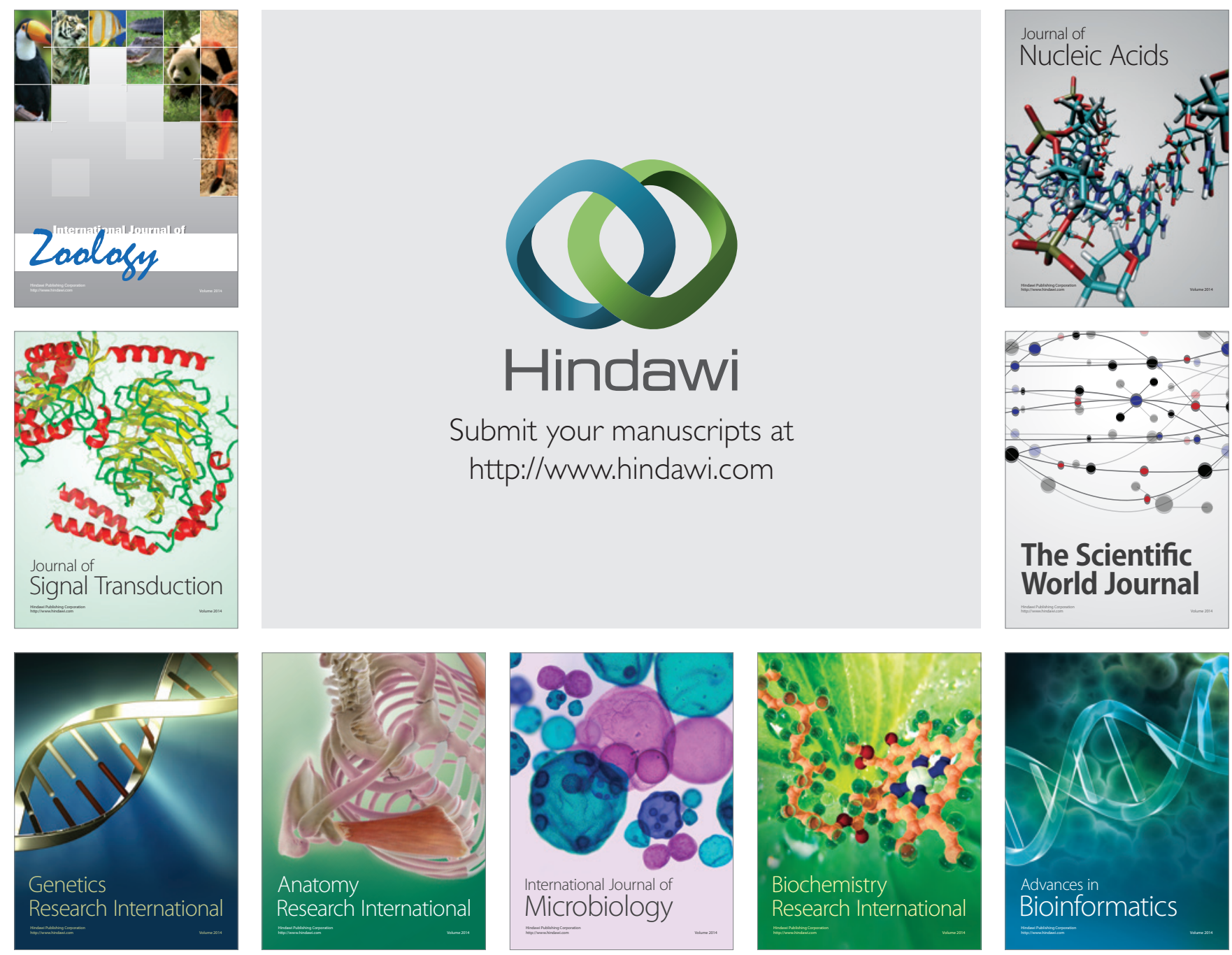

The Scientific World Journal
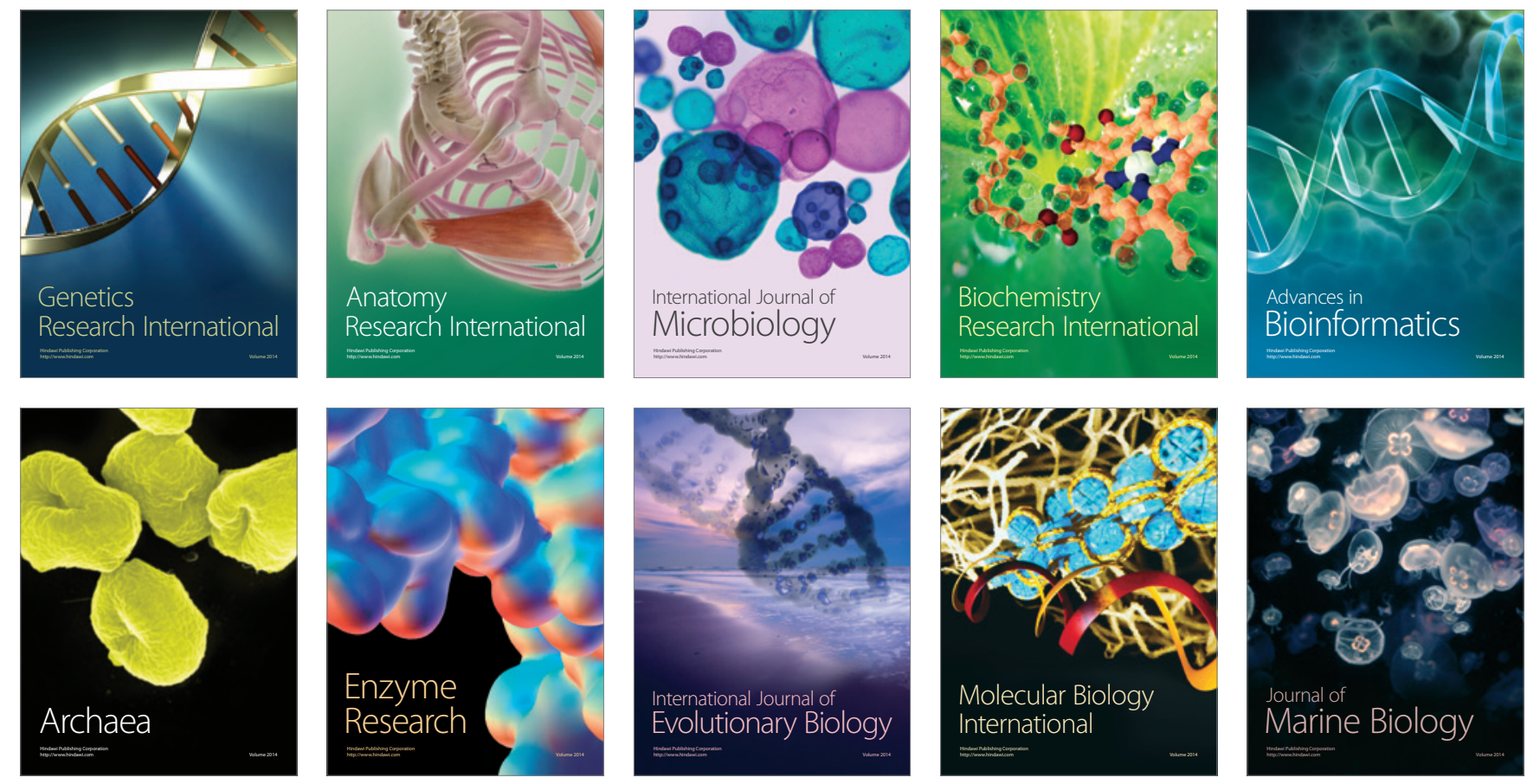